\title{
SPECTRAL ANALYSIS OF POLYMER MODIFIED BITUMEN USED IN WATERPROOFING
}

\begin{abstract}
Asphalt is one of the most commonly used building material. The first attempts at modifying asphalt were made at the beginning of the twentieth century. Nowadays the most popular asphalt modifier is the styrene-butadiene-styrene (SBS). This thermoplastic elastomer increases the thermal resistance of bitumen, widens the range of plasticity and amends rheological properties. IR spectroscopy is by far the most common instrumental method used in analytical chemistry. The popularity of this method results from its simple measurement technique, universality and high precision. That is why IR spectroscopy applies to the analysis of polymer modified binder (PMB) used in waterproofing.
\end{abstract}

Keywords: IR-spectroscopy, styrene-butadiene-styrene (SBS), quantification

\section{Introduction}

In the market of building materials bitumen products are in the forefront of the most commonly used materials, next to steel, concrete, wood or ceramic. Approximately $85 \%$ of the asphalt goes to the pavement industry [1], but much of it is also employed for waterproofing. Accordance with the European Standards, there are two types of flexible sheets for waterproofing:

- bitumen damp proof sheets including bitumen basement tanking sheets (EN 13969);

- reinforced bitumen sheets for roof waterproofing (EN 13707).

Flexible sheets for waterproofing, which are commonly called roofing felt, are made of three main composites: sheet material, bitumen and sprinkle (Fig. 1). As sheet material are used cardboard, polyester or fiberglass. Sprinkle is made of sand, basalt, feldspar or porphyry [2]. As shown in the figure 1 bitumen makes up more than $2 / 3$ of roofing felt, that is why the properties of bitumen have a decisive influence on the properties of the roofing felt. Nowadays modified bitumen is used mainly in waterproofing as well as in the pavement industry.

\footnotetext{
${ }^{1}$ Maria Ratajczak, Poznan University of Technology, Institute of Structural Engineering, ul. Piotrowo 5, 60-965 Poznań; tel. 61665 2165; maria.ratajczak@put.poznan.pl
} 


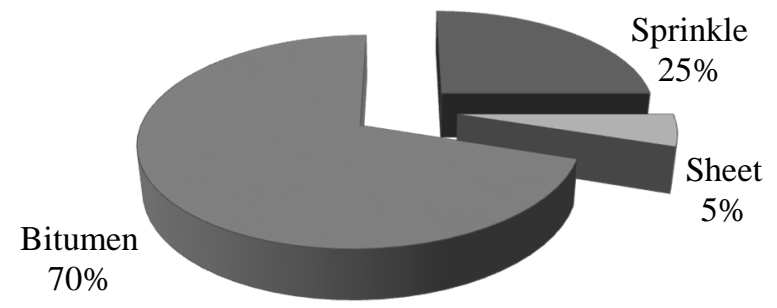

Fig. 1. Composites of roofing felt

Rys. 1. Skład papy zgrzewalnej

The first attempts of asphalt modification were made at the beginning of the twentieth century when the method of producing sulfuric asphalt, called Dubbs asphalt was developed. Another attempts made in the 50's of the twentieth century resulted in a number of methods to improve the properties of asphalt. The oil crisis in 1973 and the rapid development of polymer chemistry contributed to the development of technology of modified bitumen [3]. The most common types of modifiers used are SBS (Styrene-Butadiene-Styrene) and APP (Atactic Polypropylene). APP is mostly applied in Southern Europe, whereas the SBS is the leading one in Northern Europe.<smiles>CCCCCCC=CCCCCc1ccccc1</smiles>

Fig. 2. Structural formula of SBS, based on [4]

Rys. 2. Wzór strukturalny SBS, na podstawie [4]

Styrene-butadiene-styrene (SBS) is a thermoplastic elastomer which consists of three segments. Between two chains of polystyrene there is a chain of butadiene (Fig. 2). While polybutadiene gives SBS its rubber-like properties, polystyrene gives it its durability.

In the process of crosslinking blocks of styrene connect with blocks of butadiene and build durable, flexible and solid network, which gives its properties to modified binders. As a result of modification of SBS copolymer a distinct change is made in asphalt properties. The resulting product is characterized by:

- greater elastic and ductility (butadiene) [5];

- increasing thermal resistance - better viscosity, increasing the softening temperature (styrene) [5];

- higher resistance to rutting [5]; 
- lower risk of fractures [5];

- ability to stress relaxation [6];

- ability to elongation at tensile force [6];

- high tensile strength [6];

- widening the range of plasticity [6];

- better rheological properties $[3,6]$.

\section{Materials and Methods}

\subsection{Basic bitumen tests}

In the study were used following materials:

- 160/220 bitumen (D0),

$-160 / 220$ bitumen +3 wt $\%$ radial SBS (DR3),

- 160/220 bitumen $+6 \mathrm{wt} \%$ radial SBS (DR6),

- 160/220 bitumen +9 wt \% radial SBS (DR9),

- 160/220 bitumen + 12 wt \% radial SBS (DR12),

- 95/35 bitumen (P0),

$-95 / 35$ bitumen +2 wt $\%$ radial SBS (PR2),

$-95 / 35$ bitumen $+4 \mathrm{wt} \%$ radial SBS (PR4).

Three tests of conventional properties were conducted for these samples: softening point (Ring \& Ball method) according to PN-EN 1426, needle penetration at 25ㄷ according to PN-EN 1425 and Fraass breaking point according to PN-EN 12593.

\subsection{Spectral analysis - IR-spectroscopy}

Furthermore a spectral analysis was carried out in mid-infrared range. It is a range between 4000 and $400 \mathrm{~cm}^{-1}$. The presence of the functional group is associated with the characteristic absorption bands in the spectrum. The qualitative and quantitative analyses of the substances can be performed on the basis of the wavelength, frequencies and the shape of band. The quantitative analysis is based on the Lambert-Beer law:

$$
\mathrm{A}=\varepsilon \cdot 1 \cdot \mathrm{c}
$$

Where: A - absorbance;

$\varepsilon$ - molar absorptivity, $\mathrm{L} \cdot \mathrm{mol}^{-1} \cdot \mathrm{cm}^{-1}$;

1 - thickness of the sample, $\mathrm{cm}$;

$\mathrm{c}$ - concentration of the compound in solution, $\mathrm{mol} \cdot \mathrm{L}^{-1}$.

It must be remembered that the molar intensity of the bands is very sensitive to the intermolecular interaction, which causes instability of $\varepsilon$ factor, the deviation from the Lambert-Beer law. Measuring the integral intensity, the surface under the contour band, is time consuming and therefore the quantitative 
analysis often use the maximum intensity. This causes additional errors, because the maximum intensity is strongly dependent on the accuracy of the spectrophotometer [7]. It should be noted, that from the chart we can read the relative values of the transmittance or absorbance, according to the apparatus used, the measurement conditions, the sample composition, thickness of the sample and its concentration. In addition, carbon dioxide and water vapor, always present in a normal atmosphere, absorb IR radiation and can cause significant errors [8]. That is why using IR spectroscopy to quantitative analysis is very complicated and requires high precision.

So far a spectral analysis was possible only for liquids or gases. To conduct the spectral analysis of bitumen it was necessary to dissolve bitumen in the solvent (toluene, tetrahydrofuran, carbon disulphide). Such prepared sample was transferred on the plate made of $\mathrm{KBr}$. After evaporating the solvent, the spectra analysis was carried out. At present the parameters of spectrophotometer allow to conduct a spectra analysis of solid materials. The research presented in this paper was performed on the spectrophotometer Nicolet iS5 FT-IR. The set-up of the spectrophotometer was presented in table 1.

Table 1. Set-up of FT-IR Spectrophotometer

Tabela 1. Parametry pomiarowe dla spektrofotometru FT-IR

\begin{tabular}{|c|c|c|c|}
\hline $\begin{array}{c}\text { Component/ } \\
\text { Condition }\end{array}$ & Requirements & $\begin{array}{c}\text { Component/ } \\
\text { Condition }\end{array}$ & Requirements \\
\hline Number of sample scans & 32 & Optical velocity & 0,4747 \\
\hline Resolution & 4000 & Aperture & 100 \\
\hline Sample gain & 4,0 & Scan range & $4000-400 \mathrm{~cm}^{-1}$ \\
\hline
\end{tabular}

\section{Results \& Discussion}

\subsection{Basic bitumen tests}

At Fig. 3 and Fig. 4 were presented the results for the softening point (Ring $\&$ Ball method), needle penetration at $25 \square \mathrm{C}$ and Fraass breaking point. Although the needle penetration of both non-modified bitumen does not reach described value $(35 / 95$ bitumen $=30$ and $160 / 220$ bitumen $=151)$, the result for these bitumen are reference for modified samples. The aim of the study is the effect of polymer modification, non the properties of non-modified bitumen. However The lower penetration could an effect of the short-term ageing (technological ageing). 


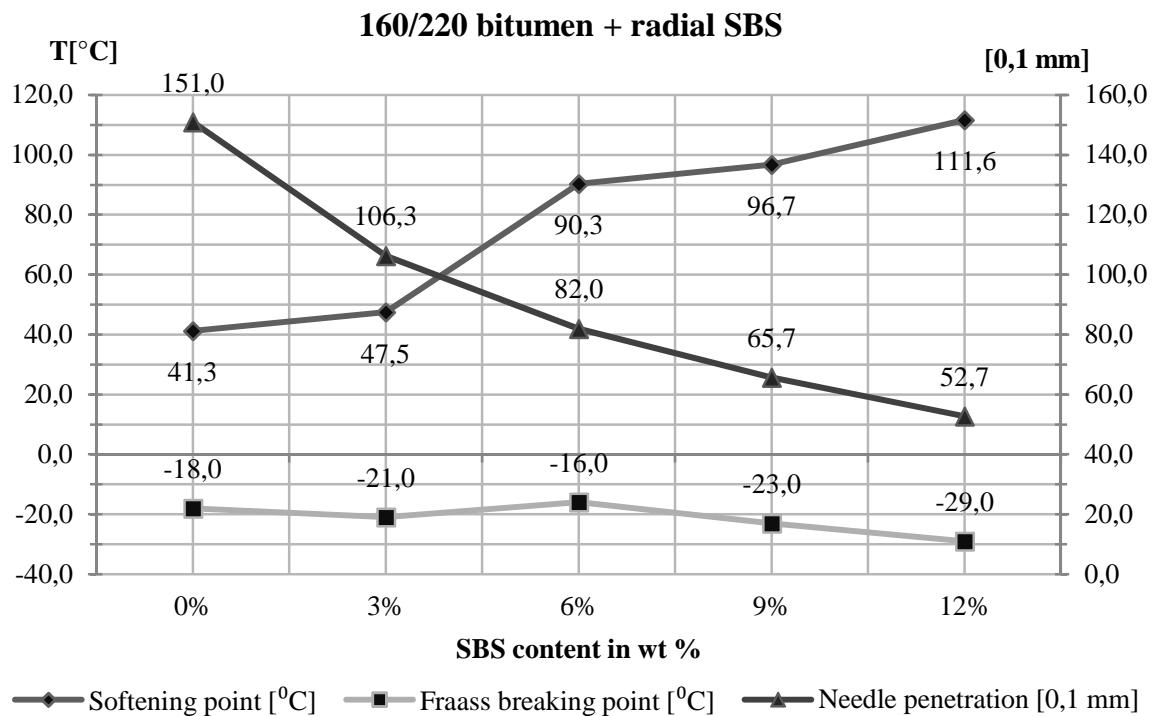

Fig. 3. Basic tests for 160/220 bitumen modified with radial SBS

Rys. 3. Wyniki badań podstawowych dla asfaltu 160/220 modyfikowanego SBS radialnym

\section{5/35 bitumen + radial SBS}

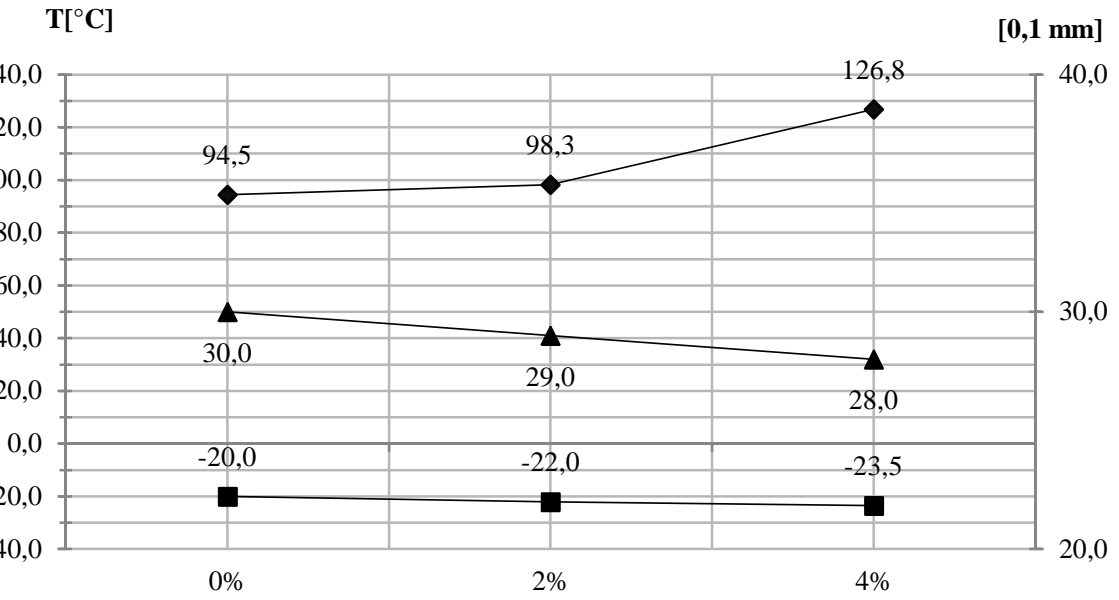

SBS content in wt \%

$\longrightarrow$ Softening point $\left[{ }^{0} \mathrm{C}\right] \longrightarrow$ Fraass breaking point $\left[{ }^{0} \mathrm{C}\right] \longrightarrow$ Needle penetration $[0,1 \mathrm{~mm}]$

Fig. 4. Basic tests for $95 / 35$ bitumen modified with radial SBS

Rys. 4. Wyniki badań podstawowych dla asfaltu 95/35 modyfikowanego SBS radialnym 
As shown in Fig. 3 and 4 the softening point increased with the increase of polymer content. The penetration grade and Fraass breaking point decreased. The increase in softening point temperature as an indicator of the stiffening effect of PMBs was favorable since bitumen with higher softening point may be less susceptible to permanent deformation. Polymer modification reduces temperature susceptibility (as determined by the penetration) of the bitumen. Lower values of penetration indicate higher temperature susceptibility [9]. The SBS content improves also the properties of bitumen in subzero temperatures. Decrease the Fraass breaking point causes better resistance to low temperatures.

\subsection{Spectral analysis}

The chemical structure of bitumen is very complicated and not fully understood. Bitumen is a highly heterogeneous mixture of hydrocarbons. The components of asphalt are classified into four classes of compounds: saturates, naphthene aromatics, polar aromatics and asphaltenes [2]. The chemical composition of bitumen is following:

Carbon $(\mathrm{C})-82 \%-87 \%$,

Hydrogen $(\mathrm{H})-10 \%-15 \%$,

Oxygen (O) $-2 \%-3 \%$,

Nitrogen $(\mathrm{N})-0,1 \%-1,0 \%$,

Sulfur (S) $-0,2 \%-7 \%$.

Fig. 5, 6 and 7 present the absorption spectra of 160/220 and 95/35 bitumen modified with radial SBS and radial SBS. In the range between $4000 \mathrm{~cm}-1$ and $2500 \mathrm{~cm}^{-1}$ there are characteristic bands for $\mathrm{C}-\mathrm{H}, \mathrm{N}-\mathrm{H}$ and $\mathrm{O}-\mathrm{H}$ bonds. Between $2500 \mathrm{~cm}^{-1}$ and $2000 \mathrm{~cm}^{-1}$ characteristic bands for $\mathrm{C} \equiv \mathrm{C}$ and $\mathrm{C} \equiv \mathrm{N}$ bonds are noticed. Between $2000 \mathrm{~cm}^{-1}$ and $1500 \mathrm{~cm}^{-1}$ characteristic bands for $\mathrm{C}=\mathrm{C}, \mathrm{C}=\mathrm{O}$ and $\mathrm{C}=\mathrm{N}$ bonds are observed. The most important range in mid-infrared is range between $1500 \mathrm{~cm}^{-1}$ and $400 \mathrm{~cm}^{-1}$, also named as fingerprint of substances. In this range characteristic bands for $\mathrm{C}-\mathrm{C}, \mathrm{C}-\mathrm{O}$ and $\mathrm{C}-\mathrm{N}$ bonds are noticed. For all the spectra we can distinguish many bands, which may be derived from hydrocarbon chains, especially in the range under $1500 \mathrm{~cm}^{-1}$.

The comparison of the absorption spectra of 160/220 and 95/35 bitumen indicates that the spectra are similar, despite the differences in physical properties and its chemical structure (exchanged the dispersed and the continuous phase). There are significant differences between the absorption spectra of non-modified and modified bitumen. For bitumen modified by SBS we distinguish characteristic bands for wavenumber at $1030 \mathrm{~cm}^{-1}, 966 \mathrm{~cm}^{-1}$ and $670 \mathrm{~cm}^{-1}$. These bands are characteristic for the SBS and represent the bond of $=\mathrm{C}-\mathrm{H}$ "out of plane". The frequencies of these three bands are also depended on the content of the polymer. Intensity of the bands increases with the addition of SBS. However, finding the relationship between the polymer content and the intensity of the band is a very complicated issue. 


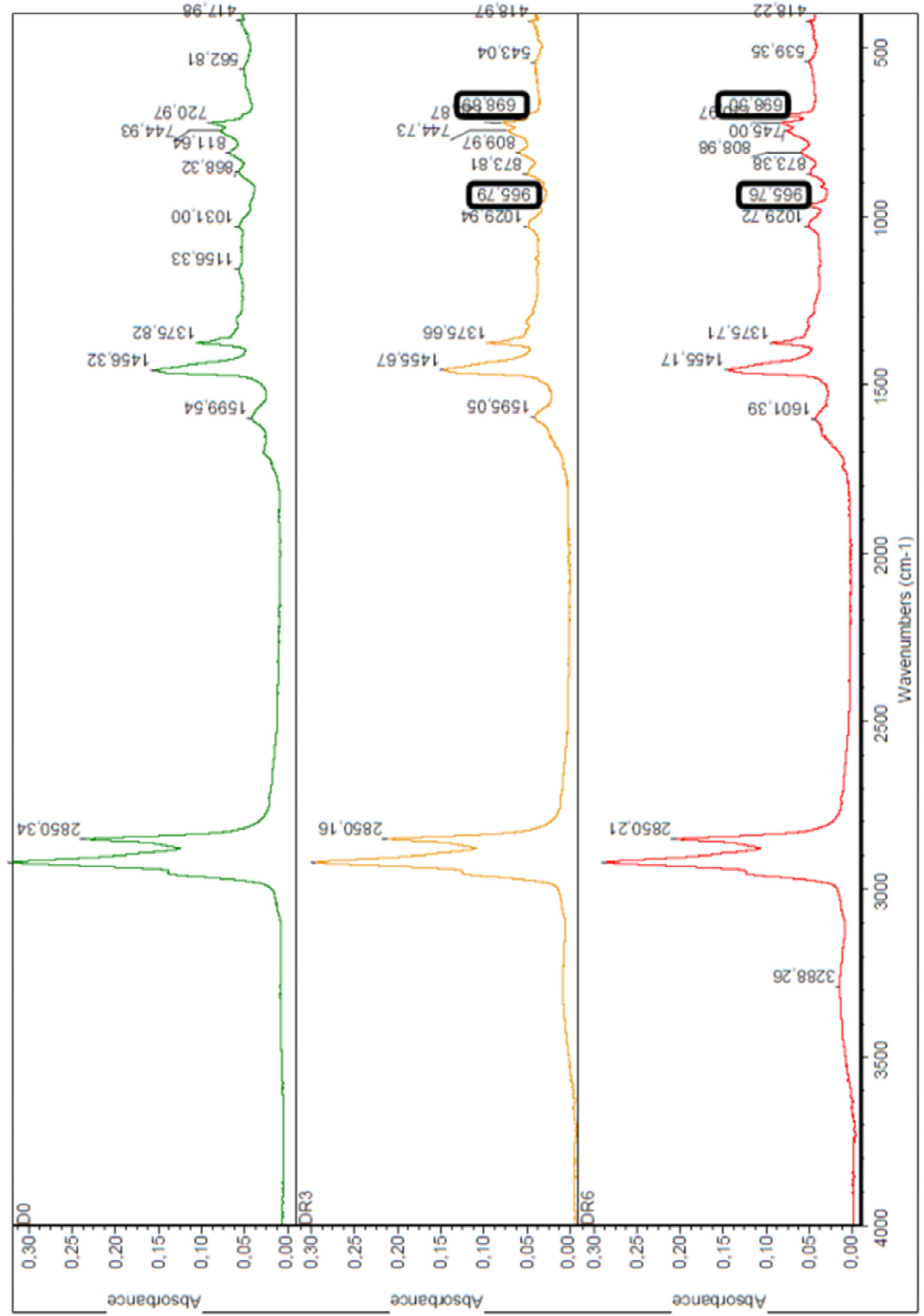

Fig. 5. Absorption spectra of 160/220 bitumen modified with radial SBS

Rys. 5. Widmo absorpcji asfaltu 160/220 modyfikowanego radialnym SBS 


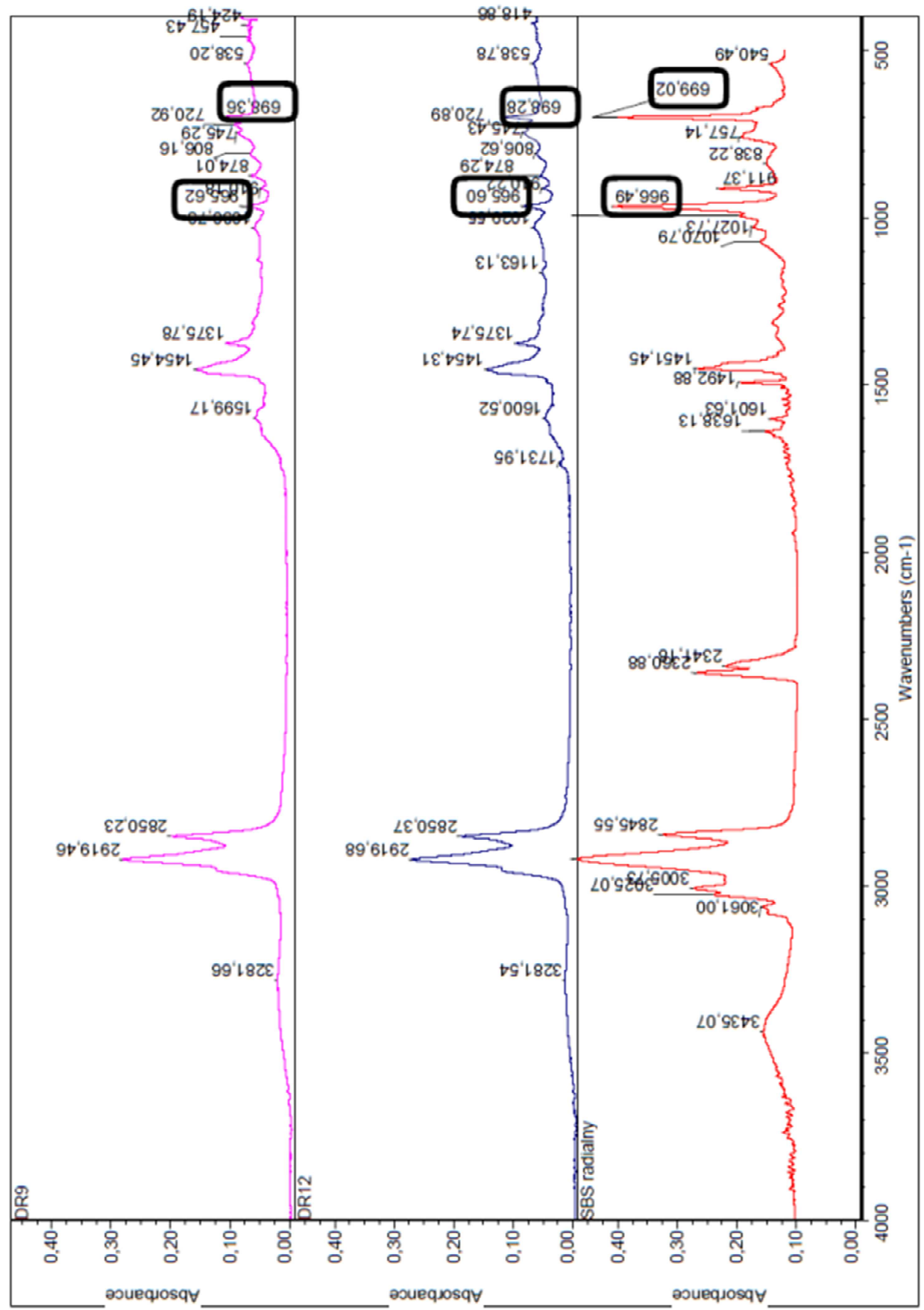

Fig. 6. Absorption spectra of SBS and 160/220 bitumen modified with radial SBS Rys. 6. Widmo absorpcji SBS oraz asfaltu 160/220 modyfikowanego radialnym SBS 


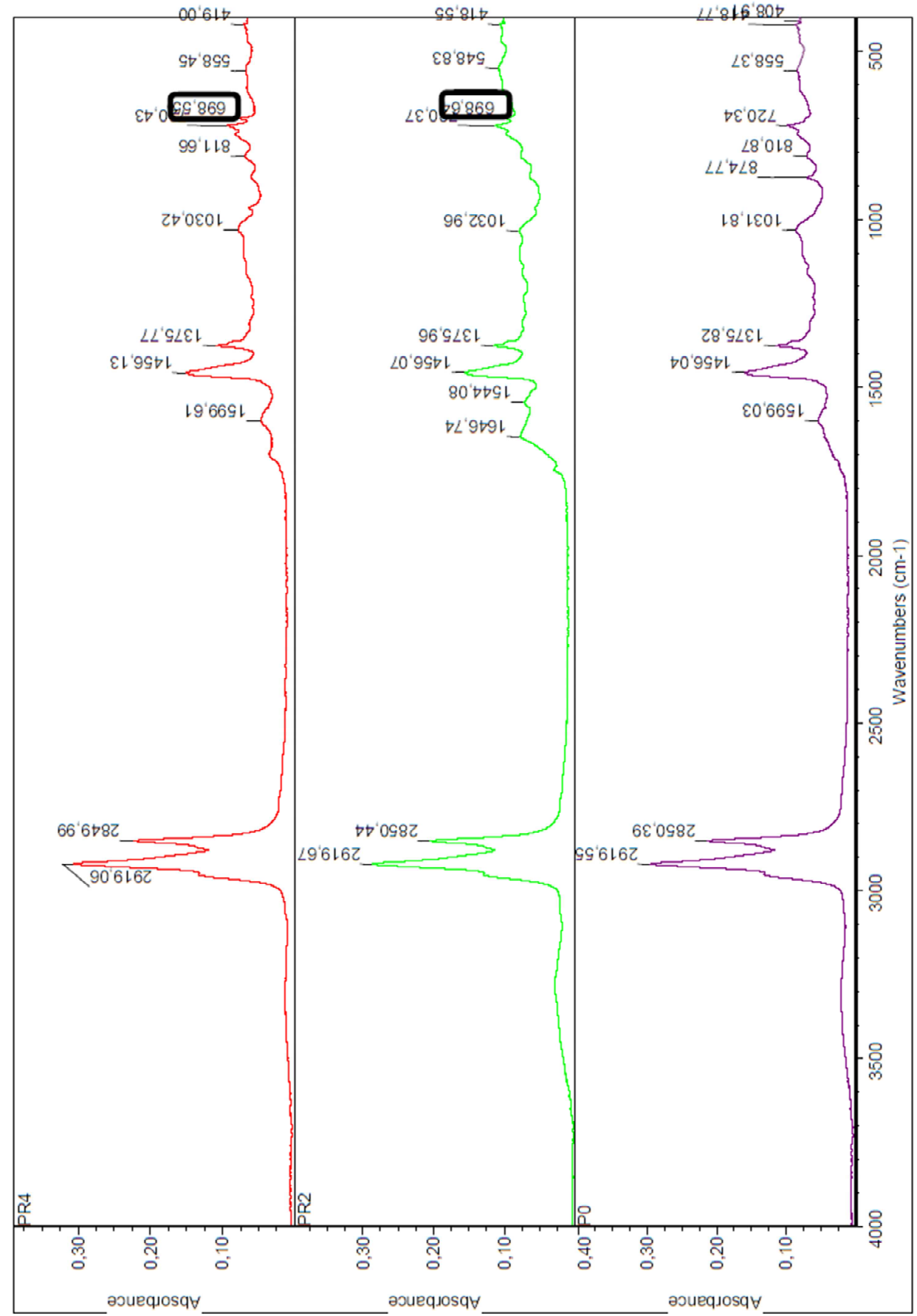

Fig. 7. Absorption spectra of $95 / 35$ bitumen modified with radial SBS

Fig. 7. Widmo absorpcji asfaltu 95/35 modyfikowanego radialnym SBS 


\section{Conclusions}

Due to increasing demands on the properties of bitumen it has become necessary to use PMB. Currently, the best and the most effective modifier is SBS. Even the small amount of SBS causes significant changes in the properties of modified asphalt. Unfortunately, the high price of the polymer is a temptation for producers to understate its content in the final product. Therefore, it is necessary to have a fast and simple method to conduct qualitative and quantitative analyses of PMB. The research confirms that IR spectroscopy was found suitable for the study. Based on the absorption spectra of PMB it is possible to determine if the bitumen was modify with SBS and the content of the SBS in modified bitumen.

\section{References}

[1] Becker Y., Mendez M. P., Rodriguez Y.: Polymer Modified Asphalt, Vision Technologica, Volume 9 (2001), p. 39-50.

[2] Stefańczyk B.: Budownictwo ogólne T.1. Materiały i wyroby budowlane, Arkady, Warszawa 2010.

[3] Zieliński K.: Rola kopolimeru SBS w kształtowaniu struktury i właściwości termomechanicznych asfaltów stosowanych w materiałach hydroizolacyjnych, Wydawnictwo Politechniki Poznańskiej, Poznań 2007.

[4] WWW user survey. (n.d.). Retrieved from http://pslc.ws/macrog/sbs.htm.

[5] Błażejowski K., Styk S.: Technologia warstw bitumicznych, Wydawnictwo Komunikacji i Łączności, Warszawa 2000.

[6] Gaweł I., Kalabińska M., Piłat J.: Asfalty drogowe, Wydawnictwo Komunikacji i Łączności, Warszawa 2001.

[7] Cygański A.: Metody spektroskopowe w chemii analitycznej, Wydawnictwo Naukowo-Techniczne, Warszawa 1997.

[8] Kęcki Z.: Podstawy spektroskopii molekularnej, Wydawnictwo Naukowe PWN, Warszawa 1998.

[9] Ghasri M. R. A., Nejad F. M., Kazemifrad S., Habibi S.: Performance evaluation of SBS/sulfur modified bitumen and its effect on fuel resistance, Journal of Applied Chemical Research, Volume 7 (2), 2013, p. 7-20.

\section{ANALIZA SPEKTRALNA ASFALTÓW MODYFIKOWANYCH POLIMERAMI STOSOWANYCH W WYROBACH HYDROIZOLACYJNYCH}

\section{Streszczenie}

Asfalt jest jednym z najczęściej stosowanych materiałów budowlanych. Pierwsze próby jego modyfikacji były podjęte na początku XX wieku. Obecnie najczęściej stosowanym modyfikatorem jest styren-butadien-styren (SBS). Ten termoplastyczny elastomer zwiększa odporność termiczną asfaltu, poszerza jego zakres lepkosprężysty oraz zmienia jego właściwości reologiczne. Spektro- 
skopia IR jest najczęściej stosowaną metodą instrumentalną w chemii analitycznej. Popularność tej metody wynika z prostoty techniki pomiaru, uniwersalności i wysokiej precyzji. Dlatego możliwe jest wykorzystanie spektroskopii w zakresie średniej podczerwieni do analizy asfaltów modyfikowanych polimerami.

Słowa kluczowe: analiza ilościowa, styren-butadien-styren, spektroskopia, średnia podczerwień

Przestano do redakcji: 02.11.2016 $\mathrm{r}$.

Przyjęto do druku: 31.03.2017 r. 